\title{
Characterization of Indian Fly ashes for Mine Stowing Purposes
}

\author{
Naik, H.K. and Mishra, M.K.
}

\begin{abstract}
The objective of this study was to select the best fly ash material which can replace river bed sand to fill underground coal mine voids. To achieve the objectives, this study examined the suitability of seven numbers of Indian fly ashes for filling in the underground coal mine voids based on their physicochemical, morphological and mineralogical characteristics. The physical properties such as bulk density, specific gravity, particle size distribution, specific surface area, porosity, moisture content, pH etc. have been determined. The chemical and mineralogical properties were also determined in the laboratory by X-ray diffraction (XRD) analysis, scanning electron microscopy (SEM), energy-dispersive X-ray spectroscopy (EDX) and X-ray fluorescence (XRF) studies. From the chemical characterization it is found that the fly ash samples are enriched predominantly with silica $\left(\mathrm{SiO}_{2}\right)$, alumina $\left(\mathrm{Al}_{2} \mathrm{O}_{3}\right)$ and iron oxides $\left(\mathrm{Fe}_{2} \mathrm{O}_{3}\right)$ along with a little amount of $\mathrm{CaO}$ and all the seven fly ash samples tested fall under the class $\mathrm{F}$ fly ash category. In addition to these, the fly ash samples also contain some trace elements in negligible amount. The mineral phases identified in the fly ash samples are quartz, mullite, magnetite, and hematite. The particle morphological analysis revealed that the fly ash particles are almost spherical in shape which would favor hydraulic pipeline transport to mine void filling areas. From the particle size and shape point of view the fly ashes tested may be considered as an alternative to conventional mine void filling material.
\end{abstract}

Keywords - Fly ash, material characterization, mine void filling, specific gravity, density

\section{Introduction}

Coal-based thermal power plants all over the world facing serious problems of handling and disposal of the ash produced. The high ash content (35-55\%) of the Indian coal makes this problem more complex. Safe disposal of the coal ash and the large storage area required are major concerns of thermal power plants. Hence attempts are made to utilize the ash rather than dump it in the vicinity of the power plants in the ash ponds. Underground voids have the maximum potential to accommodate fly ash in bulk as compared to the same in other areas of application. An in-depth understanding of the physical and chemical properties, as well as engineering and leaching behavior of fly ash is required. This paper reports the work which was carried out in this context for bulk utilization of fly ash in mine filling applications.

Literature review reveals that hydraulic sand stowing is widely used world over in underground coal mines to minimize surface subsidence. Now-a-days, the Indian mining industry is facing an acute shortage of river bed sand due to its increasing application in civil engineering

\begin{tabular}{lllll}
\hline Department of Mining & Engineering, & National & Institute \\
Technology, Rourkela, India & &
\end{tabular}

applications. As a result, a large number of underground coal mines are left unfilled after excavation of coal, which leads to surface subsidence. Thus the mining industry is searching since long for an alternative filling material which should be available in sufficient quantity near to the mine site at minimal cost. Fly ash is explored to fulfill these requirements. Fly ash which is generated in thermal power plants as a coal combustion by-product (CCB) occupies a substantial land area in the vicinity of power plants in the form of ash ponds and is responsible for various environmental pollutions and ecological imbalances. The effective bulk utilization of this unused fly ash locked in the ash ponds has emerged as a challenge for the power plant authorities and environmental scientists. Fly ash has many geotechnical applications including cement, concrete, and bricks, aggregates, and grouts, construction of embankments, as a fill material, base and sub-base coarse material (Bayat, 1998; Foner et al., 1999; Behera \& Mishra, 2011). At present only about $50 \%$ of the ash generated is being used for various applications viz. as a stabilizer of sub-grade (Pandian, 2004), and sub-bases in pavement construction (Sridharan et al., 1996), as a filling material in mines (Pandey and Kumbhakar, 2007), as a material for construction of roads and embankments (Murthy, 1996; Bumzoo et al., 2005), as a structural fill (DiGioia and Nuzzo, 1997; Leonards and Bailey, 1982) etc. There are numerous successful attempts on the utilization of fly ash either alone or mixed with lime, gypsum or both (Mishra and Rao, 2006) and it has been recognized that its use in mine filling applications has enough potential for its bulk utilization. In these studies, it has been demonstrated that the fly ash properties can be improved with addition of lime, cement, and other chemicals. Those areas cited above are hence having limitations in accommodating fly ash in bulk. Underground mine void filling is an important and major avenue for bulk utilization if attributes of fly ash can be suitably modified. For effective utilization in this area, it is desirable that the material should be chemically inert and devoid of combustible matter that might cause spontaneous heating and fire risk to coal mines. Apart from this, particle shape and size, density, specific gravity, porosity, moisture content, $\mathrm{pH}$ etc. plays important roles in transporting this material hydraulically to mine void filling areas. Therefore, the physico-chemical and mineralogical characterization is a pre-requisite before its effective utilization in mine filling applications. Such studies would be of great help in making a judicious choice for filling mine voids and evolving a methodology to work out finer details for the same. This exercise can also pin point and supplement for many other similar application areas (Moreno et al., 2005).

Table 1: Sample ID and their source of collection

\begin{tabular}{l|l|l|l} 
Sample & Source of collection of & Sample & State
\end{tabular}




\begin{tabular}{|c|c|c|c|}
\hline ID & samples & Code & \\
\hline $\mathrm{F}_{1}$ & $\begin{array}{c}\text { Ennore Thermal Power } \\
\text { Plant, Ennore }\end{array}$ & (ETPS) & Tamilnadu \\
\hline $\mathrm{F}_{2}$ & $\begin{array}{c}\text { National Aluminium } \\
\text { Company, Angul }\end{array}$ & (NALCO) & Orissa \\
\hline $\mathrm{F}_{3}$ & $\begin{array}{c}\text { IB Thermal Power Plant, } \\
\text { Jharsuguda }\end{array}$ & (OPGC) & Orissa \\
\hline $\mathrm{F}_{4}$ & $\begin{array}{c}\text { Patratu Thermal Power } \\
\text { Plant, Ranchi }\end{array}$ & (PTPS) & Jharkhand \\
\hline $\mathrm{F}_{5}$ & $\begin{array}{c}\text { Rourkela Steel Plant, } \\
\text { CPP-II, Rourkela }\end{array}$ & (RSPII) & Orissa \\
\hline $\mathrm{F}_{6}$ & $\begin{array}{c}\text { Super Thermal Power } \\
\text { Plant, NTPC, Angul }\end{array}$ & (STPP) & Orissa \\
\hline $\mathrm{F}_{7}$ & $\begin{array}{c}\text { Talcher Thermal Power } \\
\text { Plant, Talcher }\end{array}$ & (TTPS) & Orissa \\
\hline
\end{tabular}

Many researchers have conducted experimental studies in order to assess the suitability of fly ash as a mine void filling material, mine spoil amendment for vegetative reclamation, mine haul road construction, etc. (Ozerskii and Ozerskii, 2003; Dutta et al., 2009; Jirina and Jan, 2010; Ram and Masto, 2010). The fly ash particles typically range from less than $1 \mu \mathrm{m}$ to $150 \mu \mathrm{m}$ in size and are generally finer than Portland cement (Siddique, 2007). It has also been reported that fly ash is mainly composed of silt-sized material having particle dimensions ranging from about $100 \mu \mathrm{m}$ to submicron size (Chang et al., 1977; Metcalfe et al., 2006). It is found that fly ash is $25 \%$ lighter than river bed sand which will facilitate smooth flow in the pipelines as it produces less head loss and requires less energy consumption for its transportation (Ghosh et al., 2006). The chemical composition of fly ash is greatly influenced by the geological and geographical characteristics of the coal deposit, quality of coal and its degree of pulverization, the combustion techniques followed, ash handling and removal efficiencies of electrostatic precipitators or other collection devices used (Singh et al., 2002; Sarkar et al., 2006). These factors may also cause characteristics of the ash to vary, invariably, from one plant to another, sometimes even at the same power plant. The nature of the mineral matter and organic constituents in coal also determines the chemical composition of the resulting ash (Gupta et al., 1998; Liu et al., 2004). Physical properties also help in classifying the coal ashes for various engineering purposes and some are related to engineering properties. So an investigation was carried out to evaluate the suitability of fly ash from seven different sources to underground void filling characteristics. The properties investigated in this study are specific gravity, grain size distribution, specific surface area, porosity, bulk density, chemical composition, morphological characteristics, $\mathrm{pH}$, etc. Fly ash particles are spherical in shape and well graded which would offer least resistance to flow in hydraulic pipelines because of the well-known ball bearing phenomena. Fly ash with good pozzolanic properties and ultrafine particle size distribution is an ideal material for slurry preparation and pipeline transportation due to its improved fluidity and workability during filling mine voids.

Chemically, fly ash consists of silica, alumina, iron oxide, and calcium oxide with varying amounts of unburned carbon and little amount of other earth materials. The mineralogical compositions of fly ashes are identified by many researchers using powder X-ray diffraction analysis. From the X-ray diffraction spectrums, it is found that the major crystalline phases present in fly ash are quartz $\left(\mathrm{SiO}_{2}\right)$, mullite $\left(\mathrm{Al}_{6} \mathrm{Si}_{2} \mathrm{O} 13\right)$ and minor phases are iron oxides such as magnetite $\left(\mathrm{Fe}_{3} \mathrm{O}_{4}\right)$ and hematite $\left(\mathrm{Fe}_{2} \mathrm{O}_{3}\right)$ (White \& Case, 1990; Moreno et al., 2005; Metcalfe et al., 2006;). Based on the chemical composition, fly ash has been classified into two classes, i.e. class F and class C (ASTM C-618). The chief difference between class $\mathrm{F}$ and class $\mathrm{C}$ fly ash is in the amount of silica, alumina, iron oxide, calcium, and loss on ignition (LOI) present in the fly ash. When $\mathrm{SiO}_{2}+\mathrm{Al}_{2} \mathrm{O}_{3}+\mathrm{Fe}_{2} \mathrm{O}_{3}$ is $70 \%$ or more, it is described as class $\mathrm{F}$ fly ash and when this sum is between 50 and $70 \%$, then the fly ash is called a class $\mathrm{C}$ fly ash. Usually class C fly ash contains more calcium oxide than the class $\mathrm{F}$ fly ash (Vassilev \& Vassileva, 2006). The presence of $\mathrm{CaO}$ (free lime) in significant quantity in the fly ash will possess both pozzolanic and cementitious properties which is very important ingredient from strength gain point of view in the filled mass.

\section{Materials and methods}

\subsection{Materials}

Fly ash samples used in the present investigation were procured from seven numbers of different coal-fired thermal power plants as situated in different parts of the country (designated as $F_{1}, F_{2}, F_{3}, F_{4}, F_{5}, F_{6}$, and $F_{7}$ ). They were collected directly from hoppers attached to electrostatic precipitators in gunny bags and transported with care to the place of experimentation. The location details of the power plants are given in Table 1.

\subsection{Methods}

\subsubsection{Study of physical properties}

Some of the physical properties that are of particular interest when fly ash is used for filling in underground coal mine voids are particle size distribution, specific gravity, bulk density, specific surface area, moisture content, porosity, $\mathrm{pH}$, etc. Specific gravity is one of the important physical properties needed for the use of coal ashes for mine filling applications. The specific gravity $(\mathrm{G})$ of the ash samples were determined using a stopper bottle having a capacity of $50 \mathrm{ml}$ as per the guidelines provided by the American Society of Testing Materials (ASTM D 854). For the sake of accuracy, the average specific gravity was obtained from the results of five repeated tests. In general, the specific gravity of coal ash is around 2.0 but vary between 1.6 and 3.1. Because of the low value of the specific gravity of coal ashes compared to soils, ash fills tend to result in low dry densities. The reduction in unit weight is advantageous in the case of its use as a backfill material for retaining walls since the pressure exerted on the retaining structure as well as on the foundation structure will be less. The other application areas which can get benefit of low density include embankments especially on weak foundation soils, reclamation of low-lying areas, etc. The variation of specific gravity of the coal ash is attributable to a combination of many factors such as gradation, particle shape, and chemical composition. It is known that coal ash comprises mostly of glassy cenospheres and some solid spheres. The reason for a low specific gravity is either due to 
the presence of large number of hollow cenospheres from which the entrapped air cannot be removed, or the variation in the chemical composition, in particular iron content, or both. The bulk density $(\varphi)$ was determined experimentally by following the procedures of Indian standards (IS Codes, 1987) and the porosity was calculated by using the following formula:

$$
\varphi=\left(1-\frac{\rho}{G}\right) \times 100 \%
$$

The gradational properties of the fly ash samples were determined by using Malvern particle size analyzer (UK) that uses soft imaging mechanism with the wet dispersion method in water. This is a laser diffraction particle sizer which works on the principle of laser diffraction and utilizes photo sedimentation method. Grain size distribution indicates if a material is well graded, poorly graded, fine or coarse, etc. and also helps in classifying the coal ashes. Coal ashes are predominantly silt sized with some sand-size fraction. Leonards and Bailey (1982) have reported the range of gradation for fly ashes and bottom ashes which can be classified as silty sands or sandy silts. The pond ashes consist of silt-size fraction with some sand-size fraction. The bottom ashes are coarser particles consisting predominantly of sand-size fraction with some silt-size fraction. Based on the grain-size distribution, the coal ashes can be classified as sandy silt to silty sand. The values of the $D_{60}$ and $D_{10}$ for each sample were determined from the particle size distribution curves and coefficient of uniformity $\left(C_{u}\right)$ was calculated by using the following formula:

$$
\mathrm{C}_{\mathrm{u}}=\mathrm{D}_{60} / \mathrm{D}_{10}
$$

The specific surface area of the ash samples were determined by using a Blaine's apparatus (ASTM C 204) with Portland cement as the standard reference material. The following equation was used (Singh \& Kolay, 2002) to calculate the specific surface area of the ash samples:

Specific surface area $\left(\mathrm{cm}^{2} / \mathrm{g}\right)$,

$$
\mathrm{S}=\left\{\mathrm{S}_{\mathrm{s}}\left(1-\mathrm{e}_{\mathrm{s}}\right) \sqrt{ } \mathrm{e}^{3} \sqrt{\mathrm{T}}\right\} /\left\{\sqrt{ } \mathrm{e}_{\mathrm{s}}^{3} \sqrt{\mathrm{T}_{\mathrm{s}}}(1-\mathrm{e})\right\}
$$

Where $S$ is the specific surface area of the ash sample, $S_{s}$ the specific surface area of the Portland cement $\left(3460 \mathrm{~cm}^{2} / \mathrm{g}\right), e$ is the void ratio of the ash sample, $e_{s}$ the void ratio of the cement (=0.5), $T_{s}$ the measured time interval of manometer drop (for cement it is $77.18 \mathrm{~s}$ ) and $T$ is the measured time interval of manometer drop for ash sample. The study of specific surface area of soils is widely recognized as a means to understand their physical and engineering behavior. Even though coal ashes are primarily silt/sandsized particles and their specific surface is expected to be very low, results need to be obtained for completeness and for use in mine void filling applications.

Scanning electron microscopy (SEM) studies were carried out to determine the morphology of the ash particles using SEM (JEOL JSM 6480 LV, Japan). Pandian et al. (1998) demonstrated that the coal ash particles are generally cenospheres, leading to low values of specific gravity. The particle morphology of the fly ash samples were analyzed from photomicrographs. The particle shape was quantified by using image analysis and documented with photomicrographs.

\subsubsection{Study of the mineralogical composition}

\section{chemical \&}

The chemical properties of the coal ashes mainly influence the environmental impacts including contamination of surface and subsurface water with heavy toxic metals present in the coal ashes, loss of soil fertility around the plant sites, etc. that may arise out of their use/disposal as well as their engineering properties. Hence a detail data on chemical composition, morphological studies, $\mathrm{pH}$, total soluble solids etc. is necessary. Chemical compositions suggest the possible areas of application of coal ash. Roode (1987) reported that loss on ignition is generally equal to the carbon content. The amount of $\mathrm{SiO}_{2}$ or $\mathrm{SiO}_{2}+\mathrm{Al}_{2} \mathrm{O}_{3}$ in fly ash influences the pozzolanic activity. Minnick (1959) reported that a relatively high percentage of carbon decreases the pozzolanic activity. The Indian fly ashes contain silica, alumina, iron oxide, and calcium oxide. The silica content in fly ashes ranges between 38 to $63 \%$, the alumina content ranges between 27 and 44\%, the calcium oxide is in the range of 0 to $8 \%$. Thus all the Indian coal ashes satisfy the chemical requirements for use as a pozzolana. The chemical and mineralogical characterization of fly ash is not only beneficial for knowing its composition, but also helps in its classification for its possible utilization as mine void filling material.

A SEM (Model JEOL JSM 6480 LV, Japan) with EDX and auto sputter coater was used to determine the chemical composition (major elements and their oxides) of the fly ashes. Since the ash samples are non-conducting in nature, they were coated with gold with a Bio-RAD E-5200 coating unit. The chemical compositions of the ash samples, calculated as major oxides, were obtained with the help of the above EDX set-up. EDX technique was used for identifying the elemental composition of the specimens. The EDX analysis system works as an integral feature of a Scanning Electron Microscope (SEM) and cannot operate on its own without the latter. It is an analytical tool predominantly used for chemical characterization of samples. It relies on the investigation of a sample through interactions between light and matter, analyzing X-rays in its particular case i.e. each element of the periodic table has a unique electronic structure and, thus, a unique response to electromagnetic waves. Spectroscopy data is often portrayed as a graph plotting counts vs. energy. The peaks correspond to characteristic elemental emissions. The release of X-rays creates spectral lines that are highly specific to individual elements; thus, the X-ray emission data can be analyzed to characterize the sample in question.

XRF analysis was carried out in Philips PW2400 X-ray fluorescence spectrometer (XRF) machine. It provides one of the simplest, accurate and economic analytical methods for the determination of the chemical composition of many types of materials. It is non-destructive and reliable, requires little sample preparation and is suitable for solid, liquid and 
Proc. of The Eighth Intl. Conf. On Advances in Applied Science and Environmental Technology - ASET 2018 Copyright (C) Institute of Research Engineers and Doctors, USA. All rights reserved.

ISBN: 978-1-63248-155-9 doi: 10.15224/978-1-63248-155-9-33

Table 2.Physical properties of fly ash samples

\begin{tabular}{|c|c|c|c|c|c|c|c|}
\hline Parameters & $\mathrm{F}_{1}$ & $\mathrm{~F}_{2}$ & $\mathrm{~F}_{3}$ & $\mathrm{~F}_{4}$ & $\mathrm{~F}_{5}$ & $\mathrm{~F}_{6}$ & $\mathrm{~F}_{7}$ \\
\hline Colour & Gray & Gray & Gray & Dark gray & Light gray & Light gray & Light gray \\
\hline Specific gravity $(\mathrm{G})$ & 2.20 & 2.43 & 1.98 & 2.35 & 2.46 & 2.19 & 2.21 \\
\hline Bulk density $(\rho), \mathrm{g} / \mathrm{cm}^{3}$ & 1.75 & 1.6 & 1.67 & 1.89 & 1.95 & 1.99 & 1.80 \\
\hline Porosity $(\varphi), \%$ & 20.5 & 34.2 & 15.7 & 19.6 & 20.732 & 9.135 & 18.55 \\
\hline Moisture content, \% & 0.20 & 0.8 & 0.25 & 0.15 & 0.398 & 0.22 & 0.401 \\
\hline Specific surface area, $\mathrm{m}^{2} / \mathrm{g}$ & 1.24 & 1.20 & 0.458 & 0.187 & 0.408 & 0.428 & 0.395 \\
\hline Particle size analysis & & & & & & & \\
\hline $\mathrm{D}(4,3), \mu \mathrm{m}$ & 171.61 & 14.27 & 48.204 & 91.26 & 48.214 & 59.79 & 65.608 \\
\hline $\mathrm{D}(3,2), \mu \mathrm{m}$ & 8.5 & 5.04 & 13.105 & 32.05 & 13.115 & 14.003 & 15.175 \\
\hline $\mathrm{D}_{90}$ & 988.5 & 30.831 & 113.727 & 187.61 & 113.757 & 144.133 & 158.144 \\
\hline $\mathrm{D}_{50}$ & 11.2 & 8.367 & 29.972 & 74.573 & 29.871 & 39.375 & 43.47 \\
\hline $\mathrm{D}_{10}$ & 3.81 & 2.649 & 7.184 & 18.013 & 7.173 & 7.248 & 7.966 \\
\hline Coefficient of uniformity, $\mathrm{C}_{\mathrm{u}}$ & 14.8 & 1.15 & 1.12 & 0.70 & 1.13 & 1.09 & 1.07 \\
\hline
\end{tabular}

powdered samples. It can be used for a wide range of elements, from sodium (11) to uranium (92), and provides detection limits at the sub-ppm level.

The ash samples were also evaluated for their mineralogical composition by conducting XRD Spectrometer (Philips Analytical X-ray B.V.) studies, using a graphite monochromator and $\mathrm{Cu} \mathrm{K} \alpha$ radiation. The ash samples were scanned for $2 \theta$ angle ranging from $5^{\circ}$ to $80^{\circ}$. These studies were carried out primarily to identify the mineral phases. Coal ashes predominantly consist of quartz, mullite, and iron oxides such as magnetite and hematite which occur in crystalline form (Shao, 2004). Sahu (1991) reported that the nature and properties of the minerals mainly depend upon the source of coal. The process of ashification in turn controls the grain fusion, grain morphology as well as crystal growth. The mineral phases present in the collected fly ash samples were identified by XRD technique. The X-ray radiation most commonly used is that emitted by copper, whose characteristic wave length for the $\mathrm{K}$ radiation is $\lambda=1.5418 \AA$. The $\mathrm{X}$-ray diffraction patterns of the ash samples were collected by the above equipment, operated at $40 \mathrm{kV}$ and $30 \mathrm{~mA}$. The detector was scanned over a scattering angle $2 \theta$ with a $0.05^{\circ}$ step size and dwell time of $2 \mathrm{~s}$ per step. From the resulting powder diffraction patterns, the crystalline phases were identified with those in the JCPDS (Joint Committee on Powder Diffraction Standards) data files and labeled above the respective peaks (Smith and Jenkins, 1996; Erol et al., 2007).

\section{Results and discussion}

\subsection{Physical properties}

A series of tests were conducted to determine the specific gravity of the fly ash samples. The average values of specific gravity of the fly ash samples are reported in Table 2 . These values ranged from 1.98 to 2.46 , indicating a large variation between ash sources. As reported by Bumjoo et al. (2005), the wide range in specific gravity is attributable to two factors: (1) chemical composition, and (2) presence of hollow fly ash particles. The low specific gravity of fly ash samples of $F_{1}, F_{3}, F_{6}$, and $F_{7}$ are explained by their low iron oxide contents and, conversely, the high specific gravity of fly ash samples of $F_{2}, F_{4}$, and $F_{5}$ by their high iron oxide content. Different amounts of hollow particles present in fly ash samples also cause a variation in apparent specific gravity. Guo et al. (1996) examined the chemical compositions of hollow and solid fly ash particles separately, and the data revealed that hollow-particle fly ash had significantly lower iron content $(4.5 \%)$ than solid particle fly ash (25\%). The specific surface area of the fly ash samples were also determined and presented in Table 2. It varies between $0.187-1.24 \mathrm{~m}^{2} / \mathrm{g}$. The bulk density of the fly ash samples ranged between 1.60 and $1.99 \mathrm{~g} / \mathrm{cm}^{3}$. Though there is little difference in values, comparatively, the average specific gravity and bulk density of fly ashes were found to be less than that of river bed sand. The porosity of the bulk fly ash samples varied between 9.135 and $34.2 \%$.

The results of particle size analysis of the fly ash samples are summarized in Table 2 and their particle size distribution curves are shown in Figures (1-3). The particle size distribution curves of fly ash samples show more or less similar distribution patterns. The source $\mathrm{F}_{4}$ possesses the coarsest and $\mathrm{F}_{2}$ is the finest. Corresponding values of specific surface area and mean particle diameter $\left(\mathrm{D}_{50}\right)$ are $0.187 \mathrm{~m}^{2} / \mathrm{g} \& 74.573$ and $1.20 \mathrm{~m}^{2} / \mathrm{g} \& 8.367$ respectively. The grain size distributions for the fly ash samples indicated that the fly ash samples consist of sand-sized $(<4.75 \mathrm{~mm})$, silt-sized $(0.075-0.002 \mathrm{~mm})$ and clay-sized $(<0.002 \mathrm{~mm})$ particles. The ash samples are almost uniformly graded (Table 3).

Majority of particles in $F_{1}, F_{2}, F_{3}, F_{5}, F_{6}$, and $F_{7}$ fly ash samples are less than $50 \mu \mathrm{m}$ size. Only one sample i.e. $F_{4}$ fly ash has majority particles more than $50 \mu \mathrm{m}$ size. From Table 2 it is also revealed that $\mathrm{C}_{\mathrm{u}}<6$ for all the fly ash samples except fly ash sample $F_{1}$. Therefore, it may be concluded that the fly ash sample $F_{1}$ is well graded and all other samples are poorly graded as per the classification and gradation of soils (ASTM D-2487).

Table 3.Results of particle size analysis of fly ash samples

\begin{tabular}{|c|c|c|c|}
\hline \multirow{2}{*}{$\begin{array}{c}\text { Sample } \\
\text { ID }\end{array}$} & \multicolumn{3}{|c|}{ Size range (\%) } \\
\cline { 2 - 4 } & $\iota \mathbf{1} \mu \mathrm{m}$ & $1 \mu \mathrm{m}-50 \mu \mathrm{m}$ & $>50 \mu \mathrm{m}$ \\
\hline $\mathrm{F}_{1}$ & 3.66 & 87.80 & 08.54 \\
\hline $\mathrm{F}_{2}$ & 2.77 & 92.73 & 04.50 \\
\hline $\mathrm{F}_{3}$ & 1.02 & 68.20 & 30.78 \\
\hline $\mathrm{F}_{4}$ & 0.10 & 34.37 & 65.53 \\
\hline $\mathrm{F}_{5}$ & 1.02 & 68.40 & 30.58 \\
\hline $\mathrm{F}_{6}$ & 0.97 & 58.07 & 40.96 \\
\hline $\mathrm{F}_{7}$ & 0.90 & 55.16 & 43.94 \\
\hline
\end{tabular}


The SEM photomicrographs magnified at 5000x depicted the presence of particles with different shapes viz. spherical, hollow (cenosphere), broken, plerosphere (i.e. a sphere within another sphere), tubular and some other irregular shaped particles (Figures 4 and 5). SEM photomicrographs of fly ash samples show overgrowth on the surface of the ash particles due to alkali activation. Agglomeration of ash particles are also observed for $\mathrm{F}_{4}$ and $\mathrm{F}_{7}$ samples. The photomicrographs reveal that the fly ash samples consist of mostly spherical particles. The spherical ash particles with much brighter surface are identified as 'cenospheres'. The majority of the particles are spherical in shape in case of $F_{1}$ fly ash. The spherical particle morphology of the fly ash samples helps them to flow and blend freely in fly ash-water suspensions. Therefore, it can significantly improve the rheology of the slurry over conventional sand-water mixture and result in a frictionless flow in the stowing pipelines, causing less wear and tear of the pipeline inner surfaces.

\subsection{Chemical and mineralogical composition}

The major constituents of these samples are; silica $\left(\mathrm{SiO}_{2}\right)$, alumina $\left(\mathrm{Al}_{2} \mathrm{O}_{3}\right)$ and iron oxide $\left(\mathrm{Fe}_{2} \mathrm{O}_{3}\right)$. Minor quantities of calcium oxide $(\mathrm{CaO})$, magnesium oxide (MgO), sodium oxide $\left(\mathrm{Na}_{2} \mathrm{O}\right)$, potassium oxide $\left(\mathrm{K}_{2} \mathrm{O}\right)$, rutile $\left(\mathrm{TiO}_{2}\right)$ and other compounds are also observed to be present in lesser quantity. From Table 4 it is observed that in all the fly ash samples, $\mathrm{SiO}_{2}$ content ranges from 56.77 to $68.48 \%$, $\mathrm{Al}_{2} \mathrm{O}_{3}$ content ranges from 22.90 to $36.95 \%, \mathrm{Fe}_{2} \mathrm{O}_{3}$ content ranges from 0.15 to $3.52 \%$ and $\mathrm{CaO}$ content ranges from 0.36 to $2.19 \%$. The sum total of $\mathrm{SiO}_{2}, \mathrm{Al}_{2} \mathrm{O}_{3}$, and $\mathrm{Fe}_{2} \mathrm{O}_{3}$ accounts for more than $90 \%$ of the total composition in all the fly ash samples investigated. The abundance of $\mathrm{SiO}_{2}$ (about $62 \%$ of the total composition) in all the fly ash samples, would help in increasing the strength of the filling material and offer better load bearing capacity in taking the load of the overlying strata after filling the mine voids. Due to the presence of a small amount of free lime $(\mathrm{CaO})$ content $(<3 \%)$, the fly ash samples possess very negligible pozzolanic or cementing properties. Comparatively, the $\mathrm{F}_{1}$ (ETPS) fly ash sample contains higher amounts of $\mathrm{CaO}$ than the other fly ash samples and therefore, more pozzolanic in nature which is selected for further study. The presence of higher amount of $\mathrm{CaO}$ in fly ash samples helps in improving the strength of the filled mass. $F_{1}$ (ETPS) fly ash is comparatively better than other fly ashes for mine filling applications. Since the sum total of $\mathrm{SiO}_{2}, \mathrm{Al}_{2} \mathrm{O}_{3}$, and $\mathrm{Fe}_{2} \mathrm{O}_{3}$ is more than $70 \%$ and $\mathrm{CaO}$ content is less than $6 \%$ in all the fly ash samples tested, they are classified as class F fly ash (ASTM C-618).

The elemental composition of fly ash samples are presented in Table 5 which were obtained from XRF analysis. The results show that all the fly ash samples are abundant in $\mathrm{Si}$ and $\mathrm{Al}$, and possess minor concentrations of $\mathrm{Fe}, \mathrm{Ca}, \mathrm{Mg}, \mathrm{K}, \mathrm{Ti}$, and $\mathrm{P}$. In the ash samples, the elements present in decreasing order of their abundance are $\mathrm{O}, \mathrm{Si}, \mathrm{Al}$, $\mathrm{Fe}, \mathrm{Ti}, \mathrm{K}, \mathrm{Ca}, \mathrm{P}$ and $\mathrm{Mg}$.
The XRD patterns of the various fly ash samples are presented in Figures (6-9). It is noticed from the XRD patterns that the fly ash samples consist predominantly of the crystalline phase quartz, mullite, hematite and magnetite in a matrix of aluminosilicate glass. From the diffractograms it is clear that they have similar diffraction patterns. The XRD patterns of the fly ash samples have peaks characteristics of quartz $\left(\mathrm{SiO}_{2}\right)-\mathrm{Q}$, mullite $\left(\mathrm{Al}_{6} \mathrm{Si}_{2} \mathrm{O}_{13}\right)-\mathrm{M}$, and iron oxides such as magnetite $\left(\mathrm{Fe}_{3} \mathrm{O}_{4}\right)-\mathrm{U}$ and hematite $\left(\mathrm{Fe}_{2} \mathrm{O}_{3}\right)-\mathrm{U}$ which occur in crystalline form (White \& Case, 1990). However, the most common phases and minerals found in these ash samples include quartz, and mullite. Quartz may be considered as the primary mineral present in all the fly ash samples and indicated by sharp peaks in the diffraction patterns.

In all the fly ash samples, the most intense peak near $2 \theta=26^{\circ}$ is identified as the main peak due to quartz (101). Mullite or aluminosilicate mineral is also present in all the fly ash samples and the peak near $2 \theta=25.50^{\circ}$ are identified as mullite. The peaks which occur near $2 \theta=16.5^{\circ}$ are identified as refractory mullite (Sarkar et al., 2006). Along with the alumino-silicate mineral, the occurrence of strong peaks close to $2 \theta=26.49^{\circ}$ indicates quartz. The presence of heavy minerals like magnetite and hematite are identified by their respective peaks near $2 \theta=21.4^{\circ}$ and $2 \theta=26.2^{\circ}$.

\section{Conclusions}

The primary aim of this study was to select the best mine filling material out of the seven fly ashes tested to undertake further investigation. Fly ash samples tested in this study possess more or less similar physico-chemical and mineralogical properties. Comparatively, $\left(\mathrm{F}_{4}\right)$ PTPS fly ash is coarser in size and all other fly ashes are finer. The SEM photomicrographs revealed spherical particle morphology of the fly ash samples. ETPS $\left(\mathrm{F}_{1}\right)$ fly ash sample is comparatively having more number of spherical particles compared to other fly ash samples. This feature of the fly ash would create a lubricating effect due to the well-known "ball-bearing" phenomena which would result in a frictionless flow in the stowing pipelines. In addition, due to improved rheology, it would also help in reducing the energy cost in pipeline transportation during hydraulic stowing operations. ETPS fly ash is having more specific surface area which would also facilitate possible surface modification by chemical additives for smooth flow in the pipelines. The fly ash samples are mainly constituted of silica, alumina with low amounts of iron oxide and little amounts of $\mathrm{CaO}, \mathrm{MgO}, \mathrm{P}_{2} \mathrm{O}_{5}, \mathrm{~K}_{2} \mathrm{O}$, and $\mathrm{TiO}_{2}$. The presence of silica in abundance would increase the strength and the presence of $\mathrm{CaO}$ would give cementing properties after filling the mine voids. The ETPS fly ash is having good particle size distribution $\left(\mathrm{C}_{\mathrm{u}}>6\right)$ compared to other fly ashes. Therefore, out of the seven fly ashes studied it is concluded that the ETPS fly ash possess more favorable properties compared to other fly ashes for stowing in underground coal mine voids. 
Proc. of The Eighth Intl. Conf. On Advances in Applied Science and Environmental Technology - ASET 2018 Copyright ( $($ Institute of Research Engineers and Doctors, USA. All rights reserved.

ISBN: 978-1-63248-155-9 doi: 10.15224/978-1-63248-155-9-33

Table 4.Chemical composition of fly ashes obtained from EDX study

\begin{tabular}{|c|c|c|c|c|c|c|c|c|}
\hline \multirow{2}{*}{$\begin{array}{c}\text { Sample } \\
\text { ID }\end{array}$} & \multicolumn{7}{|c|}{ Elements (weight \%) } \\
\cline { 2 - 9 } & $\mathrm{SiO}_{2}$ & $\mathrm{Al}_{2} \mathrm{O}_{3}$ & $\mathrm{Fe}_{2} \mathrm{O}_{3}$ & $\mathrm{CaO}$ & $\mathrm{K}_{2} \mathrm{O}$ & $\mathrm{TiO}_{2}$ & $\mathrm{Na}_{2} \mathrm{O}$ & $\mathrm{MgO}$ \\
\hline $\mathrm{F}_{1}$ & 56.77 & 31.83 & 2.82 & 0.78 & 1.96 & 2.77 & 0.68 & 2.39 \\
\hline $\mathrm{F}_{2}$ & 59.15 & 34.80 & 3.52 & 0.76 & 2.62 & 1.14 & 0.05 & 0.05 \\
\hline $\mathrm{F}_{3}$ & 59.64 & 35.60 & 0.86 & 0.85 & 1.86 & 0.91 & 0.06 & 0.67 \\
\hline $\mathrm{F}_{4}$ & 68.48 & 22.90 & 0.15 & 0.36 & 0.91 & 1.46 & 0.03 & 0.06 \\
\hline $\mathrm{F}_{5}$ & 62.41 & 31.65 & 0.17 & 2.19 & 2.63 & 0.00 & 3.42 & 0.08 \\
\hline $\mathrm{F}_{6}$ & 62.25 & 30.47 & 2.48 & 1.92 & 1.39 & 0.58 & 0.02 & 1.90 \\
\hline $\mathrm{F}_{7}$ & 61.46 & 36.95 & 0.59 & 2.02 & 2.01 & 0.31 & 0.07 & 0.26 \\
\hline
\end{tabular}

Table 5.Elemental composition of fly ashes obtained from XRF study

\begin{tabular}{|c|c|c|c|c|c|c|c|c|}
\hline \multirow{2}{*}{$\begin{array}{c}\text { Elements/ } \\
\text { Sample ID }\end{array}$} & FA-1 & FA-2 & FA-3 & FA-4 & FA-5 & FA-6 & FA-7 & FA-8 \\
\cline { 2 - 9 } & ETPS & NALCO & OPGC & PTPS & RSP & STPS & TTPS & ZPS \\
\hline $\mathrm{Ca}$ & 0.58 & 0.479 & 0.416 & 0.456 & 0.476 & 0.588 & 0.497 & 0.263 \\
\hline $\mathrm{Fe}$ & 3.84 & 3.73 & 3.26 & 4.41 & 4.84 & 4.46 & 3.47 & 3.15 \\
\hline $\mathrm{K}$ & 0.76 & 0.685 & 0.78 & 1.07 & 0.918 & 1.13 & 0.62 & 0.92 \\
\hline $\mathrm{Mg}$ & 0.314 & 0.309 & 0.274 & 0.228 & 0.347 & 0.464 & 0.203 & 0.327 \\
\hline $\mathrm{Na}$ & 0.086 & 0.070 & 0.056 & 0.064 & 0.075 & 0.082 & 0.058 & 0.067 \\
\hline $\mathrm{P}$ & 0.157 & 0.142 & 0.062 & 0.116 & 0.137 & 0.210 & 0.123 & 0.112 \\
\hline $\mathrm{S}$ & 0.044 & 0.072 & 0.025 & 0.033 & 0.124 & 0.040 & 0.029 & 0.055 \\
\hline $\mathrm{Si}$ & 21.56 & 19.97 & 20.31 & 19.98 & 18.48 & 20.96 & 20.73 & 20.89 \\
\hline $\mathrm{Ti}$ & 1.145 & 1.286 & 1.099 & 1.087 & 0.989 & 1.01 & 1.195 & 1.239 \\
\hline $\mathrm{Al}$ & 16.14 & 17.70 & 15.29 & 13.95 & 13.418 & 15.79 & 15.58 & 17.516 \\
\hline
\end{tabular}

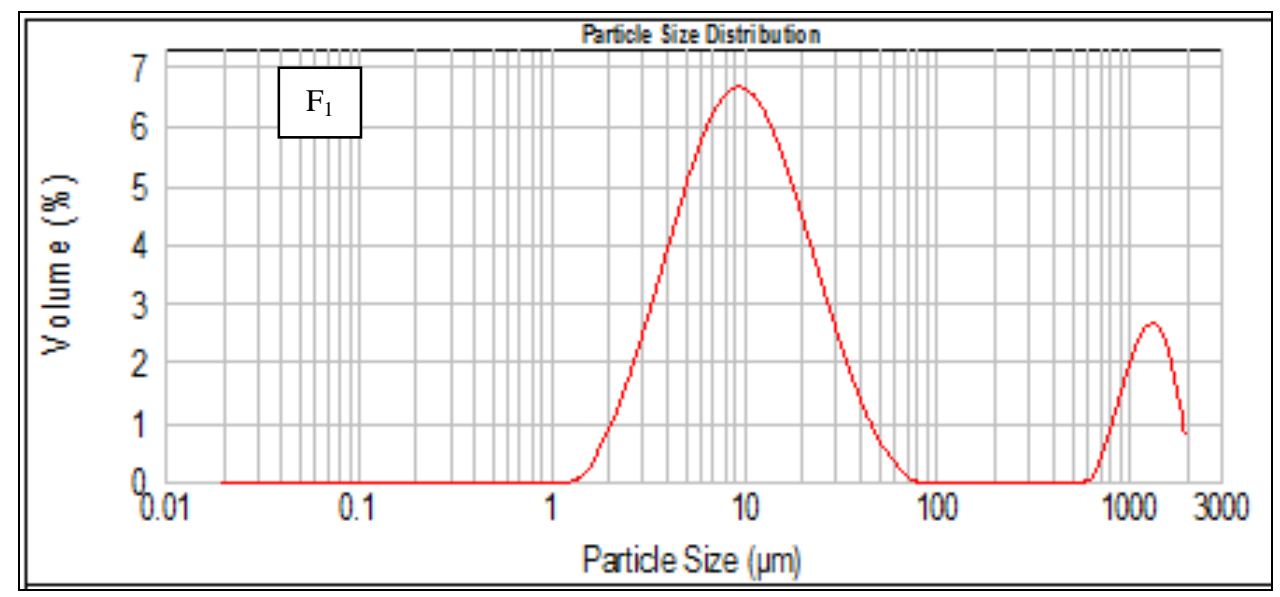

Figure 1.Particle size distribution curve of fly ash sample $\mathrm{F}_{1}$

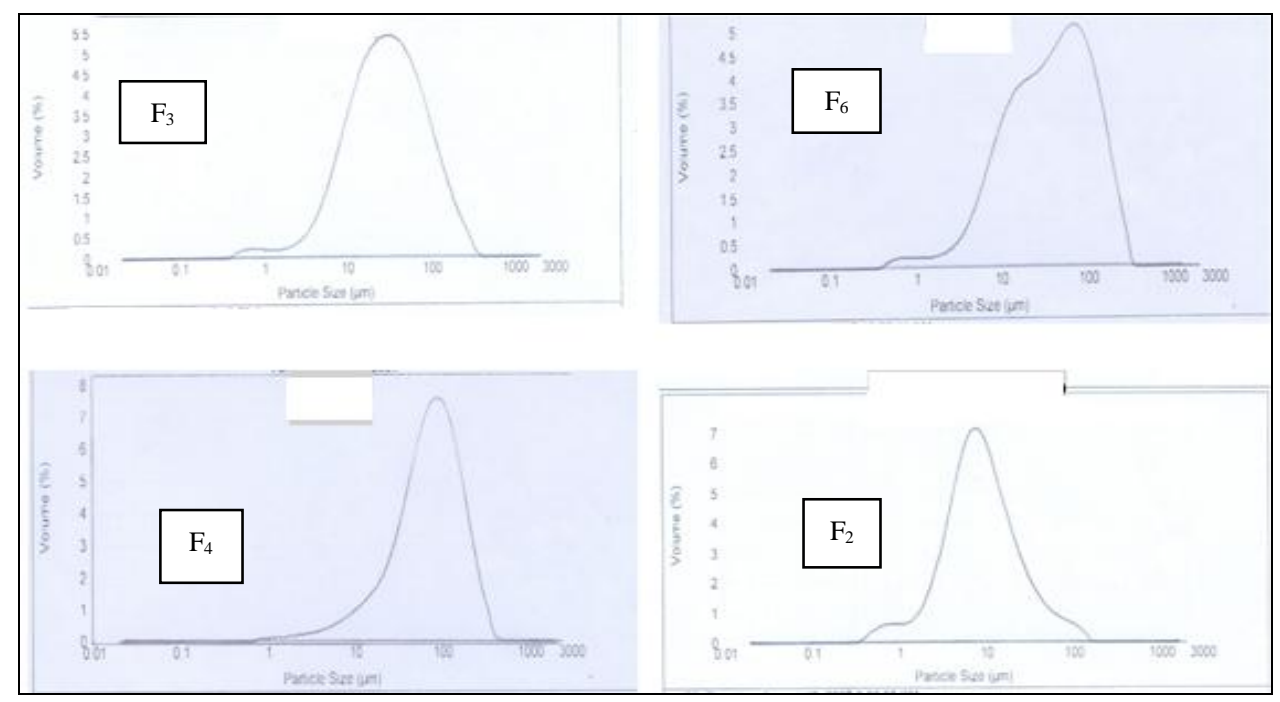

Figure 2.Particle size distribution curve of fly ash samples $F_{3}, F_{6}, F_{4}$ and $F_{2}$ 
Proc. of The Eighth Intl. Conf. On Advances in Applied Science and Environmental Technology - ASET 2018 Copyright (@) Institute of Research Engineers and Doctors, USA. All rights reserved.

ISBN: 978-1-63248-155-9 doi: 10.15224/978-1-63248-155-9-33

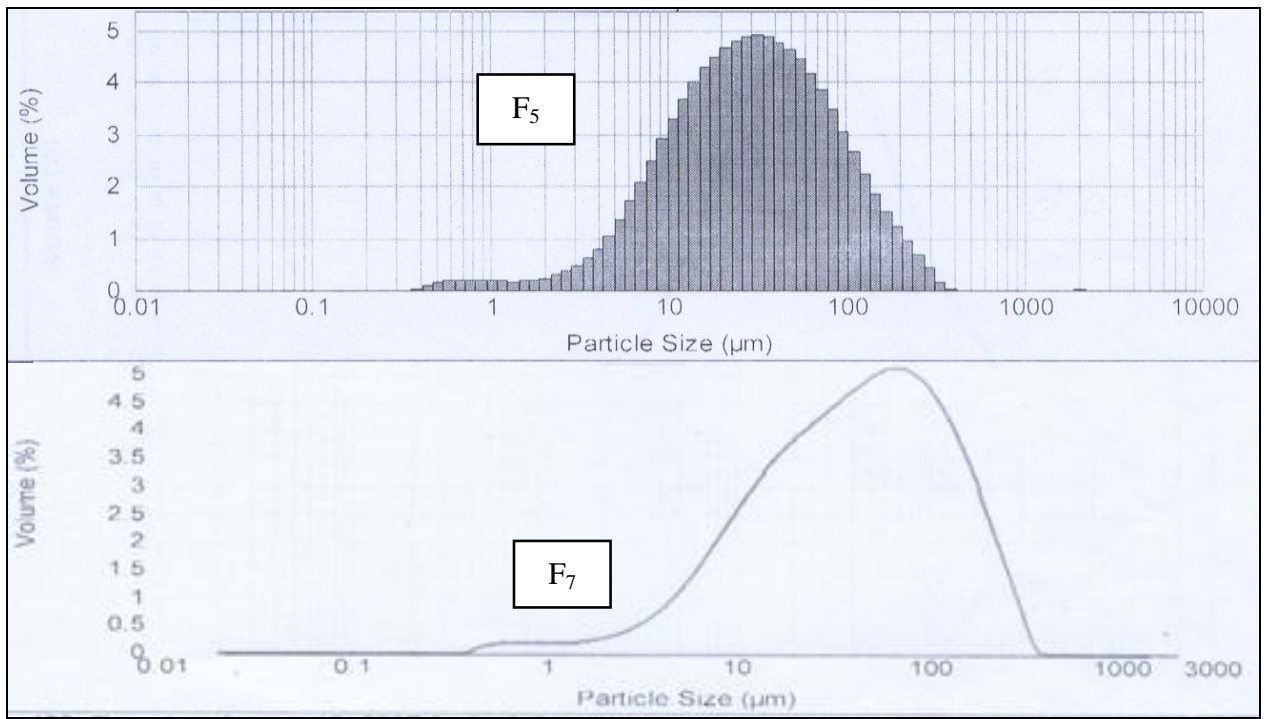

Figure 3.Particle size distribution curve of fly ash samples $F_{5}$ and $F_{7}$
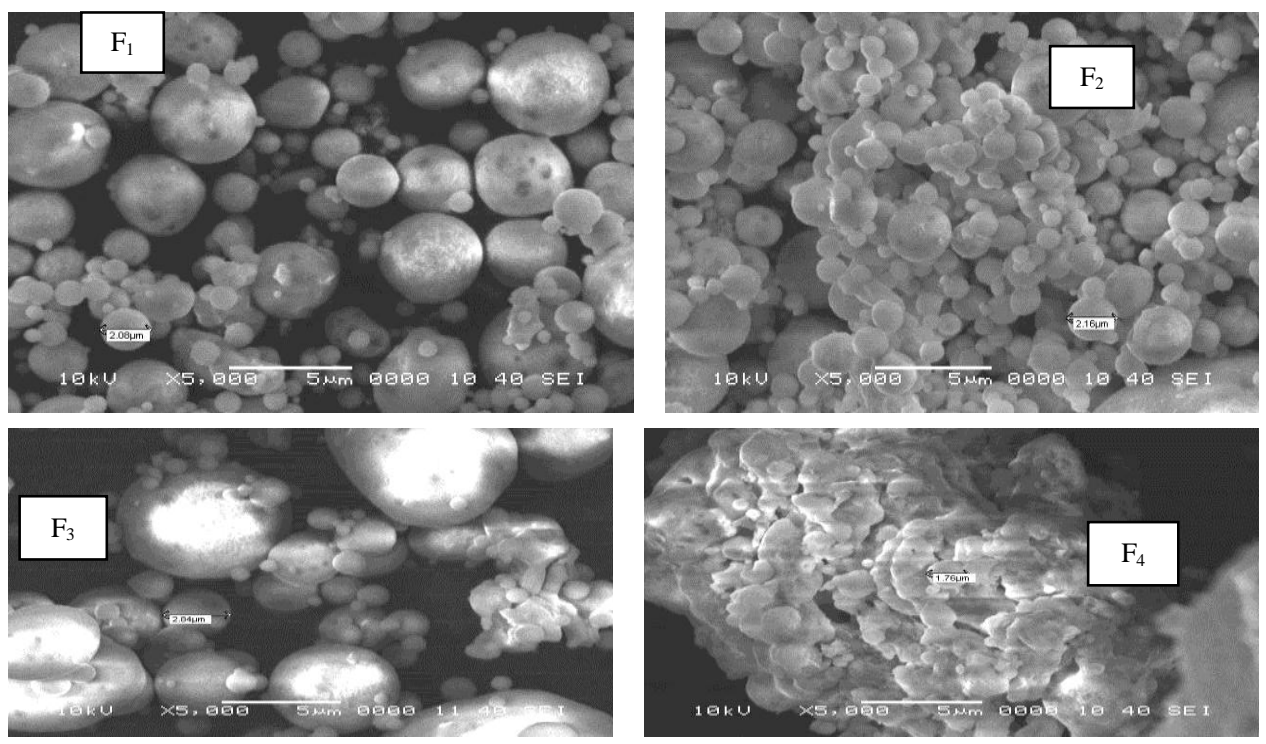

Figure 4.SEM Photomicrographs of $\mathrm{F}_{1}, \mathrm{~F}_{2}, \mathrm{~F}_{3}$ and $\mathrm{F}_{4}$ fly ash samples at 5000x
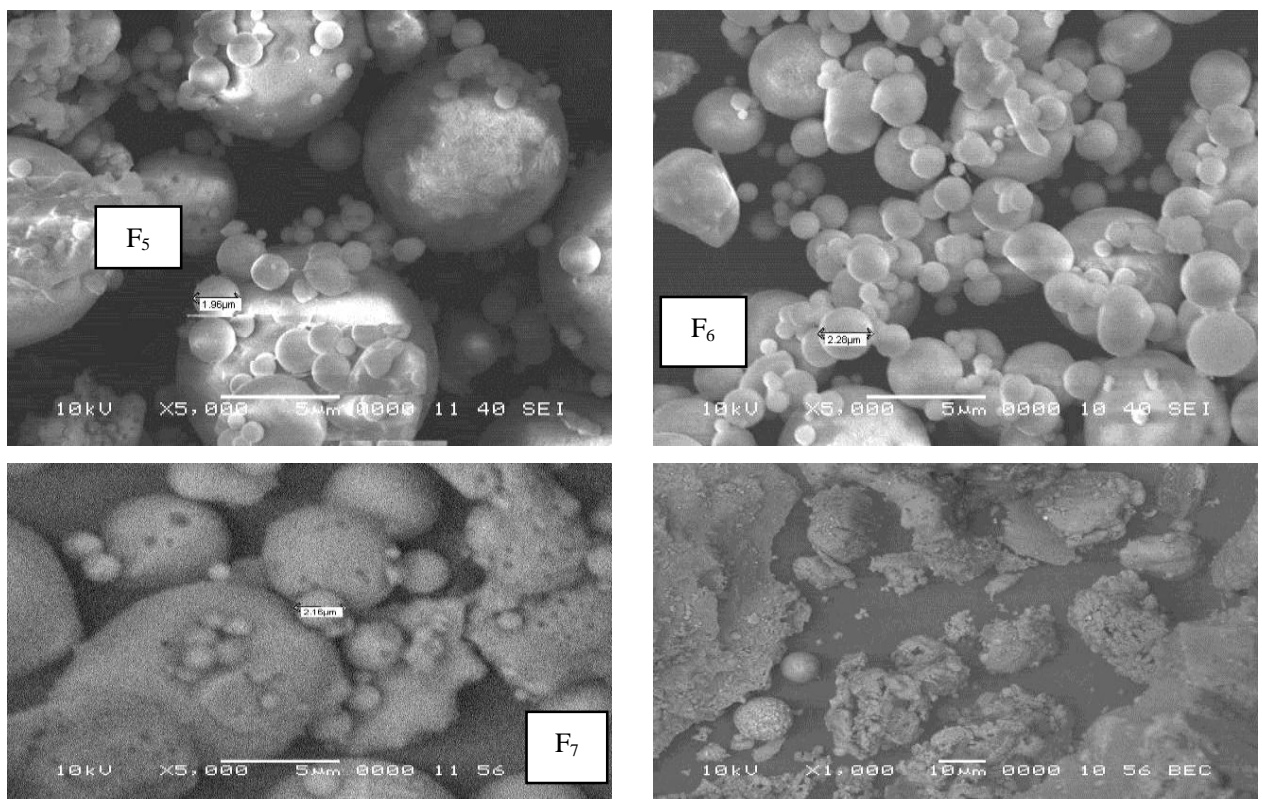

Figure 5.SEM Photomicrographs of $\mathrm{F}_{5}, \mathrm{~F}_{6}$, and $\mathrm{F}_{7}$ fly ash samples at 5000x and 1000x 
Proc. of The Eighth Intl. Conf. On Advances in Applied Science and Environmental Technology - ASET 2018 Copyright (C) Institute of Research Engineers and Doctors, USA. All rights reserved.

ISBN: 978-1-63248-155-9 doi: 10.15224/978-1-63248-155-9-33

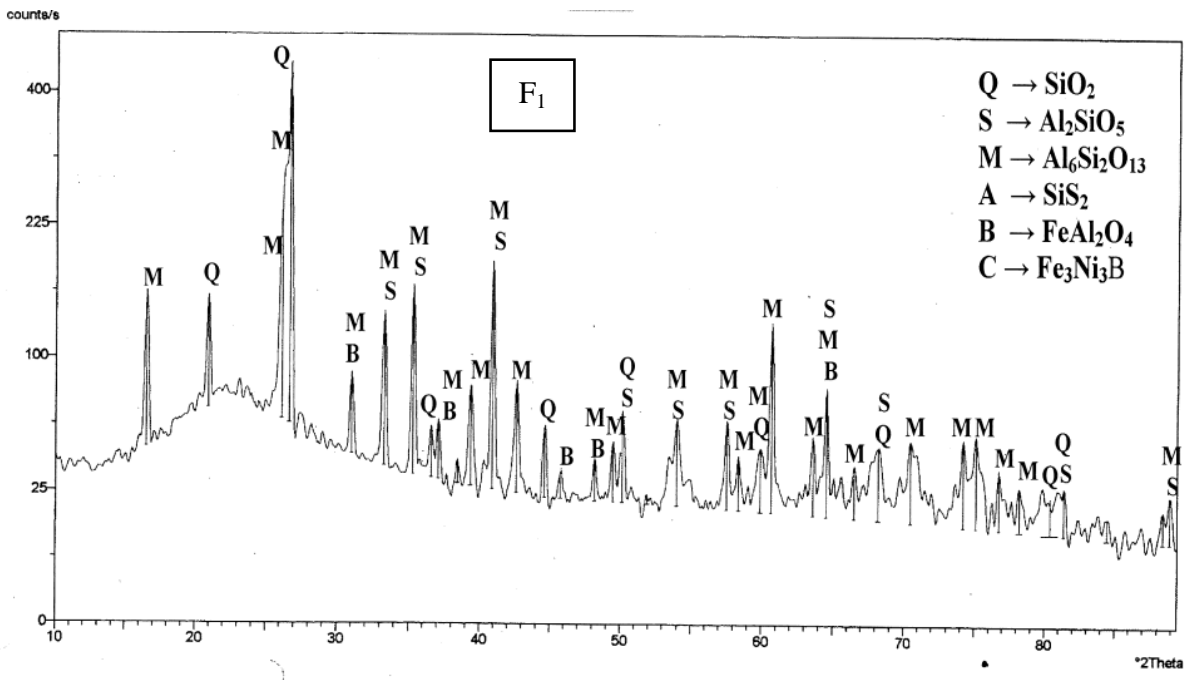

Figure 6.XRD Pattern of $F_{1}$ fly ash sample

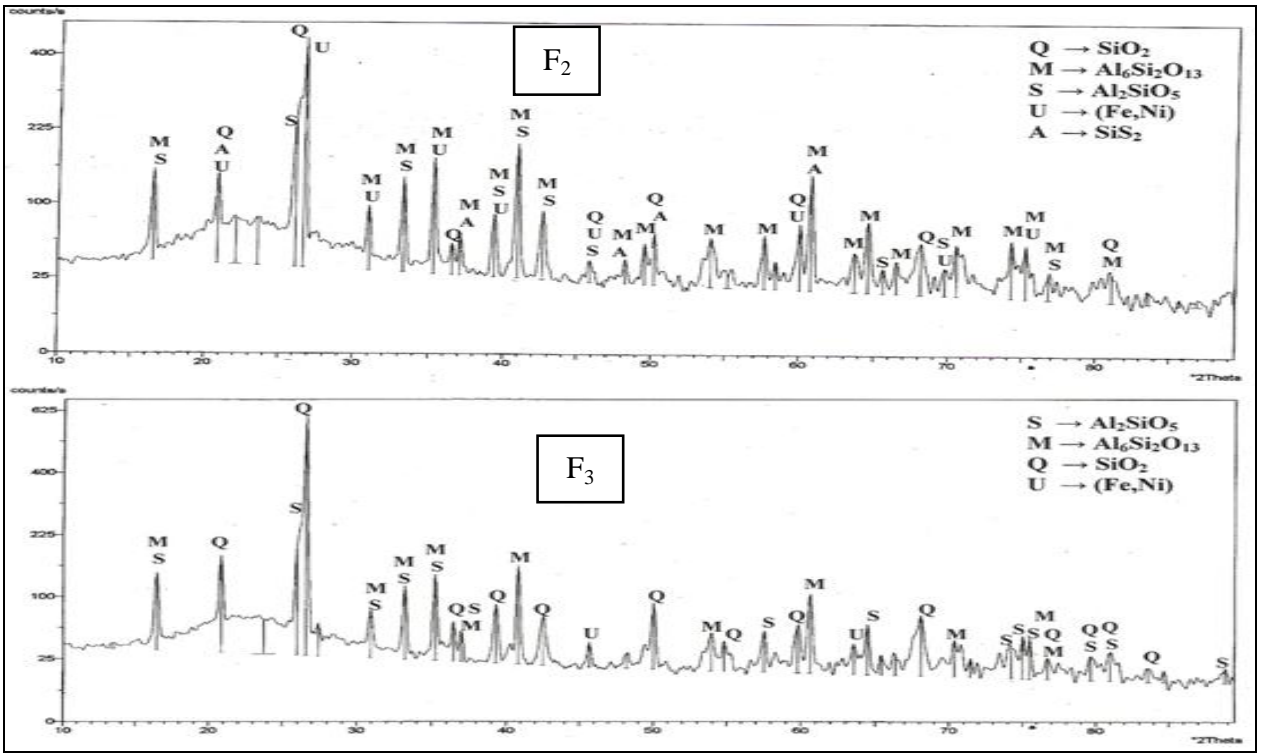

Figure 7.XRD Pattern of $F_{2} \& F_{3}$ fly ash samples

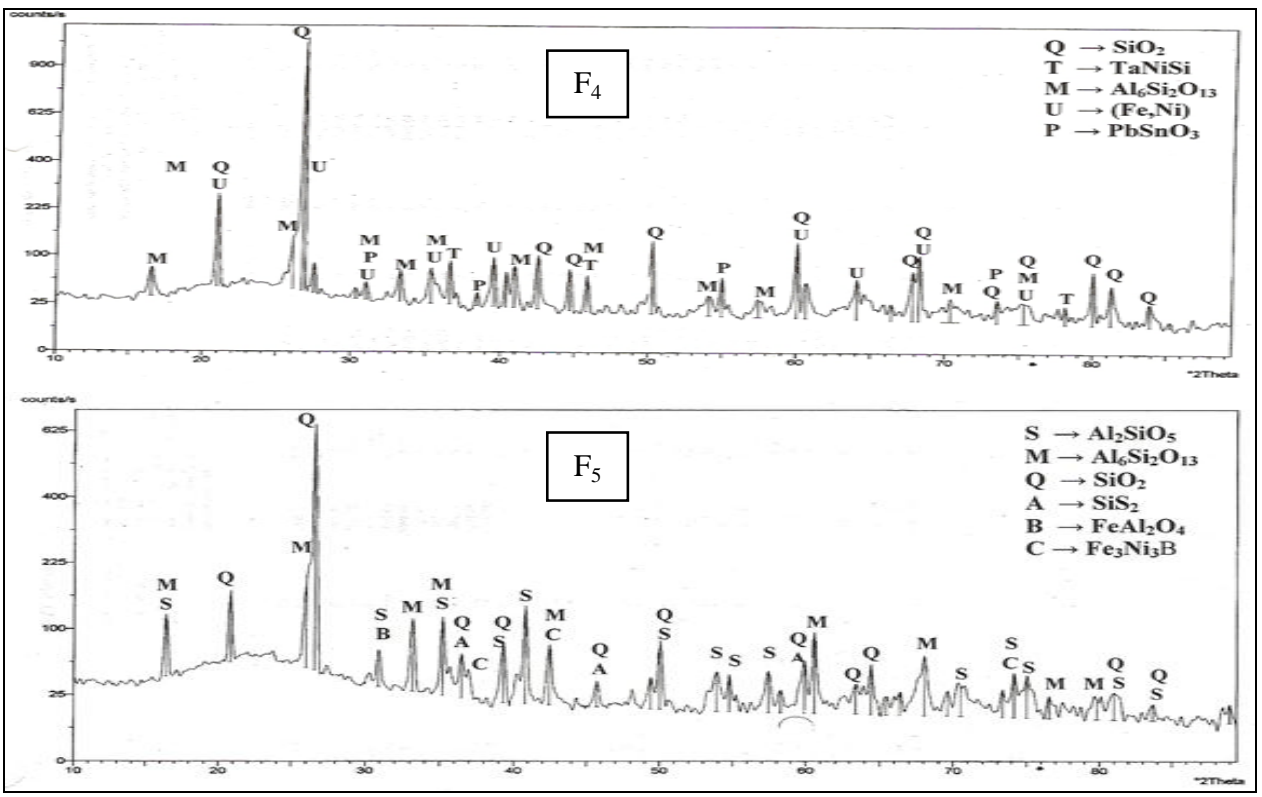

Figure 8.XRD Pattern of $\mathrm{F}_{4}$ and $\mathrm{F}_{5}$ fly ash sample 


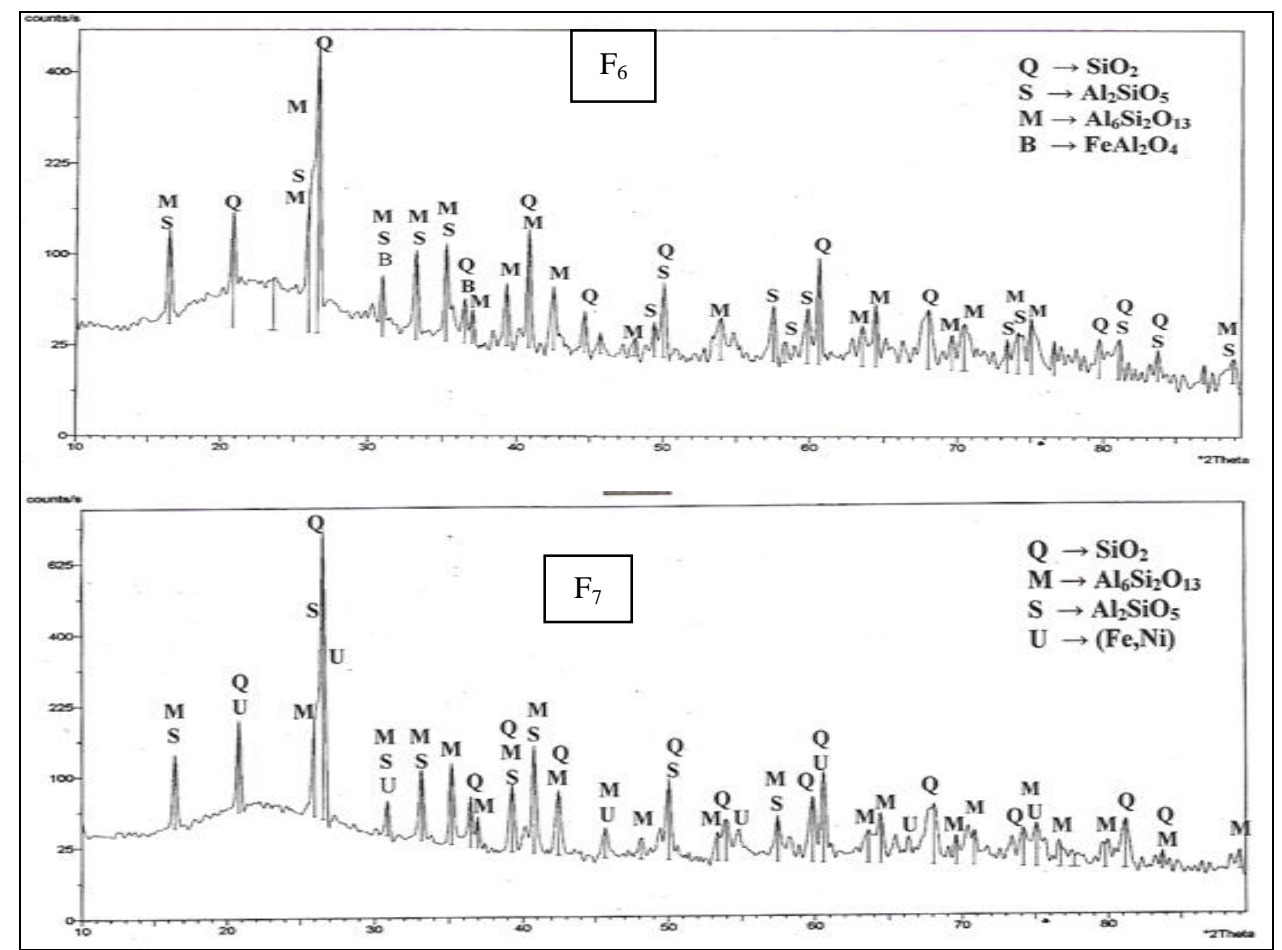

Figure 9.XRD Pattern of $\mathrm{F}_{6}$ and $\mathrm{F}_{7}$ fly ash sample

\section{References}

ASTM C 20484 Standard Test method for fineness of Portland cement by air permeability apparatus Annual Book of ASTM Standards, American Society for Testing and Materials, Philadelphia Vol.04.01, 1984, 56-162.

ASTM C 61894 Standard Specification for coal Fly ash and raw or calcined natural pozzolana for use as a mineral admixture in Portland cement concrete. Annual Book of ASTM Standards, American Society for Testing and Materials, Philadelphia, Vol.04.08, 1995, 304-306.

ASTM D 2487-11 Standard Practices for Classification of Soils for Engineering Purposes (Unified Soil Classification System).

ASTM D 854 - 92 Standard test methods for specific gravity of soils. Annual Book of ASTM Standards, American Society for Testing and Materials, Philadelphia, Vol. 04.08, 1995, 80-83.

Bayat, O., 1998.Characterization of Turkish fly ashes. Fuel 77, 1059-1066.

Behera, B., Mishra, M.K., 2011. Strength behaviour of surface coal mine overburden - fly ash mixes stabilized with quick lime. Int. Journal of Mining, Reclamation and Environment, DOI: 10. 1080/17480930.2011.552285.

Bumjoo, K., Monica, P., Rodrigo, S. 2005.Geotechnical properties of fly and bottom ash mixtures for use in highway embankments. Journal of Geotechnical and GeoEnvironmental Engineering 131, 914-924.

Bunn, T.F., Chambers, A.J., 1993. Experiences with dense phase hydraulic conveying of Vales point fly ash. International Journal of Powder Handling and Processing 5, 35-45.

Chang, A.C., Lund, L.J., Page, A.L., Warneke, J.E., 1977. Physical properties of fly ash amended soils. Journal of Environ Quality 6, 267-270.

DiGioia, A.M., Nuzzo, W.L., 1997.Fly ash as structural fill. Journal of Powder Division ASCE 98, 77-92.
Dutta, B.K., Khanra, S., Mallick, D., 2009. Leaching of elements from coal fly ash- assessment of its potential for use in filling abandoned coal mines. Fuel 88, 1314-1323.

Erol, M., Kucukbayrak, S., Ersoy-Mericboyu, A., 2007. Characterization of coal fly ash for possible utilization in glass production. Fuel 86, 706-714.

Foner, H.A., Robl, T.L., Hower, J.C., Graham, U.M., 1999. Characterization of fly ash from Israel with reference to its possible utilization. Fuel 78, 215-223.

Ghosh, C.N., Mondal, P.K., Prashant, 2006. Suitability of fly ash as a stowing material for underground coal mines- some studies. Proc. $1^{\text {st }}$ Asian Mining Congress, Kolkata, 16-18.

Guo, R.Q., Rohatgi, P.K., Nath, D., 1996. Compacting characteristics of aluminium-fly ash powder mixtures. Journal of Material Science 31, 5513-5519.

Gupta, R.P., Wall, T.F., Kajigaya, I., Miyamae, S., Tsumita, Y., 1998. Computer controlled scanning electron microscopy of minerals in coal- implications for ash deposition. Progress in Energy \& Combustion Science 24, 523-543.

IS Codes, 1987 Compendium of Indian Standards on Soil Engineering, Part-I, Bureau of Indian Standards, Nov., New Delhi, India.

Jirina, T., Jan, S., 2010. Reduction of surface subsidence risk by fly ash exploitation as filling material in deep mining areas. Natural Hazards 53, 251-258.

Leonards, G.A., Bailey, B., 1982.Pulverized coal ash as structural fill. Journal of Geotechnical Engineering Division, ASCE 108, 517-531.

Liu, G., Zhang, H., Gao, L., Zheng, L., Peng, Z., 2004.Petrological and mineralogical characterizations and chemical composition of coal ashes from power plants in Yanzhou mining district, China. Fuel Process Technology 85, 1635-1646.

Metcalfe, R.D., Connor, J.N., Druskovich, D., Blackford, M.G., Short, K., 2006.The influence of fly ash morphology and phase distribution on collection in an electrostatic precipitator. Paper No. WC0083. Proceeding of 
Australian Institute of Physics, $17^{\text {th }}$ National Congress, Brisbane.

Minnick, L.J., 1959. Fundamental characteristics of pulverized coal fly ashes. Proc. ASTM 59, 1155-1177.

Mishra, D., Das, S.K., 2010. A study of physico-chemical and mineralogical properties of Talcher coal fly ash for stowing in underground coal mines. Materials Characterization 61, 1252-1259.

Mishra, M.K., Rao, K.U.M., 2006. Geotechnical characterization of fly ash composites for backfilling mine voids. Journal of Geotechnical and Geological Engineering 24, 17491765.

Moreno, N., Querol, X., Andres, J.M., Stanton, K., Towler, M., Nugteren, H., 2005.Physico-chemical characteristics of European pulverized coal combustion fly ashes. Fuel 84, 1351-1363.

Murty, A.V.S.R., 1996.Fly ash in construction of roads and embankments. Ash ponds and Disposal Systems (V.S.Raju et al.,eds), Narosa publishing House, New Delhi,222-37.

Murty, A.V.S.R., 1998.Utilization of fly ash for embankment construction. Proc. of Experience sharing meets on use of fly ash in roads and embankments. CRRI, New Delhi, 520

Ozerskii, A.Y., Ozerskii, D.A., 2003. Disposal of ash and slag waste of the Berezovsk state regional power plant in the Berezovskii-1 mined-out space: a promising direction of environmental protection in the region. Powder Technology \& Engineering 37, 248-251.

Pandey, J.K., Kumbhakar, D., 2007.Coal ash as mine-fill: Possibilities \& Prospects. The Indian Mining \& Engineering Journal 46, 23-27.

Pandian, N.S., 2004. Fly ash characterization with reference to geotechnical applications. Journal of Indian Institute of Science 84, 189-216.

Pandian, N.S., Balasubramanian, S., 1999. Permeability and consolidation behaviour of fly ashes. Journal of Testing \& Evaluation 27, 337-342.

Pandian, N.S., Rajasekhar, C., Sridharan, A., 1998. Studies on the specific gravity of some Indian coal ashes. Journal of Testing and Evaluation, ASTM 26, 177-186.
Ram, L.C., Masto, R.E., 2010. An appraisal of the potential use of fly ash for reclaiming coal mine spoil. Journal of Environmental Management 91, 603-617.

Roode, M.V. 1987. X-ray Diffraction Measurement of Glass Content in fly ashes and slag. Concrete Research 17, 183-197.

Sahu, K.C., 1991. Coal and fly ash problem. Proc. Intl. Conf. on Environmental impact of coal utilization from raw materials to waste resources (K.C. Sahu, ed.), Indian Institute of Technology, Bombay, pp: 11-12.

Sarkar, A., Rano, A., Udaybhanu, G., Basu, A.K., 2006.A comprehensive characterization of fly ash from a thermal power plant in Eastern India. Fuel Process Technology 87, 259-277.

Seshadri, V., Singh, S.N., Jain, K.K., Verma, A.K., 2005.Rheology of fly ash slurries at high concentrations and its application to the design of high concentration slurry disposal system (HCSD), Proc of the International Conference on Fly Ash Utilization, New Delhi, V.1.1-10.

Shao, H., Liang, K., Zhou, F., Wang, G., Peng, F., 2004. Characterisation of cordierite-based glass ceramics produced from fly ash. Non-Crystal Solids 337, 157-160.

Siddique, R., 2007. Coal fly ash- waste materials and by-products in concrete, Berlin Heidelberg: Springer, 177-234.

Singh, D.N., Kolay, P.K., 2002. Simulation of ash-water interaction and its influence on ash characterization. Journal of Progress in Energy and Combustion Science $28,267-299$

Smith, D.K., Jenkins, R., 1996. The powder diffraction file: past, present, and future. Journal of Research of the National Institute of Standards and Technology 101, 259

Sridharan, A., Pandian, N.S., Rajasekhar, C., 1996. Geotechnical Characterization of pond ash. Ash ponds and Disposal Systems (V.S.Raju et al., eds), Narosa publishing House, New Delhi, 97-110.

Vassilev, S.V., Vassileva, C.G., 2006.A new approach for the classification of coal fly ashes based on their origin, composition, properties, and behaviour. Fuel 86, 14901512.

[1] White, S.C., Case, E.D., 1990.Characterization of fly ash from coal-fired power plants. Journal of Material Science 25, 52155219.

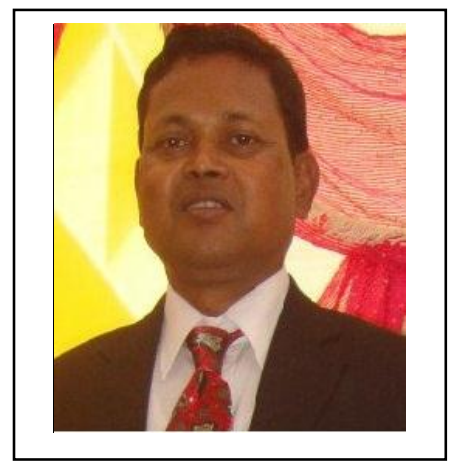

Prof. Hrushikesh Naik graduated in the year 1984 from the then Regional Engineering College (Presently NIT), Rourkela in Mining Engineering. He obtained his M.Tech. degree (Specialization in Open Cast Mining) from Indian Institute of Technology (ISM) University, Dhanbad. Served Coal India Limited for one year in an underground coal mines as under manager. Then he decided to serve his Almamater and joined as a faculty member in the year 1985 in the Department of Mining Engineering, NIT Rourkela. He was Head of the Department for three years and he was also Project Officer and Head of the Nodal Centre for Orissa (NTMIS). He visited Southern Illinois University, Carbndale, USA in the year 2006 and Kentucky University, Lexington, USA, in the year 2009 and Colorado School of Mines, Denver, USA in 2011 to upgrade his knowledge. To his credit he has got more than 25 research articles published in National and International Journals and Conference Proceedings. His areas of interest are Surface Mining, Mine Surveying, Fly Ash Management and Utilization. 